Hajduova, Z., Klimek, M., Daneshjo, N., \& Prokopenko, O. (2019). Competitiveness of Franklin Templeton Fund Managers: Do the Fund Managers Exceed the Benchmark? Journal of Competitiveness, 11(2), 70-86. https://doi.org/10.7441/joc.2019.03.05

\title{
COMPETITIVENESS OF FRANKLIN TEMPLETON FUND MANAGERS: DO THE FUND MANAGERS EXCEED THE BENCHMARK?
}

\author{
- Zuzana Hajduova, Miroslav Klimek, Naqibullab Daneshjo, \\ Olha Prokopenko
}

\begin{abstract}
Franklin Templeton Investments is a worldwide asset management company that provides services to clients in more than 170 countries. Unlike investment funds, mutual funds do not have legal personality, therefore they are merely baskets that associate assets. High past equity returns are not a guarantee of future earnings. Individual funds are often praised for the positive results they have achieved in the past, but even experienced portfolio managers cannot guarantee future returns despite their past successes in the market. The main purpose of this paper is to compare the competitiveness of Franklin Templeton fund managers. Among the time-tested indicators and suitable markers for our research on the validation of an active mutual fund with its benchmark index, the information ratio and sharp ratio have been included in the present study. Recent studies suggest that fund managers cannot achieve better results than those set in their benchmark. Managers do not utilize a simple set-up with a given portfolio, and thus their competitiveness would seem to compare unfavorably to results achieved by so-called passive investment. It can be noted that over the course of 15 years, the longest single time period that was analyzed, out of 22 equity funds, only four sets of results exceeded the benchmark. However, if regular fees are also taken into consideration to reflect more pragmatically the benefits for the investor, none of the funds analyzed in the present study failed to overcome the set benchmark during this period.
\end{abstract}

Keywords: mutual funds, investments, portfolio, earnings, competitiveness, portfolio managers JEL Classification: E22

Received: January, 2019

1st Revision: March, 2019

Accepted: June, 2019

\section{INTRODUCTION}

In recent years, a heated debate has emerged concerning the successes and failures of fund managers to invest effectively in client assets. In this case, "effectively" indicates that the fund manager should achieve better results than his/her benchmark, better performance, or lower volatility with regard to the ideal of benchmark and / or performance. Many authors have exam- 
ined these issues, e.g. Olivares-Caminal and Bodellini, 2018; Mura et al., 2017; Okanazu, 2018; Horecký, 2018; Poliačiková, 2015; Marszk, 2018. The topic of fund management and benchmarks is quite relevant at the present time, as results can help today's investors to select a stock portfolio with the greatest potential profitability. Should the individual investor choose instruments according to company statements and other information available publicly, or entrust this selection to a fund manager, an investment professional who is supposed to be an expert in the field? Or are fund managers mainly better suited for low cost and index investments? Answers to these questions might employ information regarding the theory of efficient markets, since if the investor believes in market efficiency, he will be inclined to employ low-cost investments in terms of index funds with the assumption that individual titles would not achieve better results. Conversely, an investor who believes that the market is inefficient will choose a course that seeks to achieve better results than those set by benchmark, even at the cost of paying higher fees. Nevertheless, here it is necessary to mention that if the market is inefficient, a particular investor will obtain information himself and will be able to use it in a timely manner, and will thus achieve more competitive results.

Recent studies suggest that fund managers cannot achieve better results than those set in their benchmark. Managers do not utilize a simple set-up with a given portfolio, and thus their competitiveness would seem to compare unfavorably to results achieved by so-called passive investment. Results from a study by Barras et al. (2006), in which the relatively new false discovery rate was used to assess the performance of unit trusts, may seem disquieting to ordinary investors who are convinced of the advantages of active portfolio management. Other authors scrutinized the performance of over 2,000 mutual funds and came to the conclusion that only $0.6 \%$ of these funds proved to actually defeat the market (Barras et al., 2006; Galloppo \& Aliano, 2018; Vychytilova, 2018; Sosnowski, 2018). Along with these studies, others have shown similar outcomes in recent years. Investors should should learn from the mistakes that have already been made. Two studies worth mentioning were developed by Eugene Fama of the University of Chicago and Kenneth French of Dartmouth College in which they analyzed the performance of 3,126 actively managed equity funds in the US between 1984 and 2006. The researchers found that the above-average results achieved by some funds were for the most part coincidental. Almost no retirement fund can achieve long-term better results than those which would be found generally in the market, and lay investors are not in a position to discern the funds that might achieve good results by accident from the few funds they make themselves. The study also showed that investors who invested in low-cost index funds achieved the same good results as did the top 3 percent of the funds in the study. This has encouraged us to test the success and competitiveness of equity fund managers of Franklin Templeton, which is currently considered one of the world's most reputed asset management firms.

\section{THEORETICAL BACKGROUND}

Personal services must be under the control of banks, legal acts, funds and managers (Žulová et al., 2018; Mura \& Vlacseková, 2018; Sosnowski, 2018; Korauš et al., 2019; Veselovská et al., 2018). Franklin Templeton Investments is a worldwide asset management company that provides services to clients in more than 170 countries. It provides asset management focusing on provid- 
ing relevant investment solutions, strong long-term results, and personal services. Franklin Templeton Investments is currently considered one of the most trusted names in financial services. Founded in 1947, Franklin Templeton Investments employs experienced investment professionals to cover market capitalization of all types. The company has been investing for more than 60 years. Franklin Templeton Investments is a pioneer in managing equity in global, international and emerging markets, preserving the heritage of one culture, one philosophy and one process for the benefit of investors since 1940 .

The company is divided into short-term money, bond, mixed and equity funds. Short-term funds include the Franklin Euro Short-Term Money Market Fund, which is focused on the European market. The portfolio is made up of eurobonds, securities, euro-denominated currencies, with the total amount invested around EUR 77.26 million. Management fees are $0.8 \%$, with the entry fee $1.5 \%$. For bond markets, Franklin Templeton focuses on Europe, with charges at 5\% input and management fee $1.5 \%$. The total volume at their disposal is $\$ 22.74$ million, with $90 \%$ formed by bonds and the rest in cash. The Templeton Global Balanced Fund is divided within a portfolio in which $65 \%$ are stocks, $20 \%$ are bonds and $15 \%$ is cash, with the remainder cash equivalents. Collective investment is at $\$ 938$ million. The entry fee is $5.75 \%$ and the management fee is $1.6 \%$ for portfolio management (London Stock Exchange Group, 2016).

Another equity fund is Franklin Mutual European Fund, which has a value of EUR 1.81 billion and invests in equity securities from companies in Europe. The entry fee is 5.75\% and the management fee is $1.83 \%$ of the invested amount. Investments are made in the financial, consumer and industrial sectors (Franklin Euro short-term money market fund, 2016).

\subsection{ACTIVE PORTFOLIO MANAGEMENT}

The essence of active investing is to overcome the market, which means achieving a higher return than the market benchmark. This determines the value that managers are trying to achieve or, if necessary, to overcome. This makes it possible to determine objectively which manager has been successful and was able to meet the set goals. Benchmarking is therefore a systematic process aimed at comparing efficiency in terms of productivity, quality and, last but not least, practice with top companies and organizations (Chovancová et al., 2012).

The term benchlearning stems from benchmarking. Benchlearning reflects a process that explains the impact of benchmarking on corporate and corporate development. It basically concerns acquiring new knowledge based on benchmarking (Chovancová et al., 2012, p. 154).

One question that has emerged over the last few years is whether or not the market can be in fact be defeated by actively managed funds. Recent studies suggest that most funds cannot, and those that cannot be detected in advance: "A miniscule 4 percent of funds produce market-beating after-tax results with a scant of $0.6 \%$ (annual) margin of gain. The $96 \%$ of funds that fail to meet or beat the Vanguard 500 Index Fund lose by a wealth-destroying margin of $4.8 \%$ per annum" (Bogle, 2007).

Several such claims have been made by internationally well-known authors:

" $60 \%$ to two-thirds of funds - of active funds - each year are beaten by the index, and those that win in one year are not necessarily the ones that win in the next year. Yeah, there are some War- 
ren Buffetts around, and there will probably be a couple in the future, but it is like looking for a needle in a haystack. The general result is that indexing fares well in quiet markets, volatile markets, in any kind of market. So I do not think that being active can do better in volatile markets. It simply is not true" (Malkiel, 2010).

"I don't believe in picking individual stocks or assets. As for actively-managed funds, I never saw the point of paying someone large fees for sub-standard returns. Never invest your money as though you are gambling at the casino. Buying and selling individual stocks is a waste of time" (Roubini, 2018).

Index funds can be characterized as an open-ended investment instrument that tracks and copies a particular market index. The investor has the option to compile his/her portfolio by collecting all the investments in the index in the same proportion as they are represented in the index. Thus index fund results cannot overcome the results of the index itself. The average yield on index funds generally exceeds the average returns of actively managed funds (Chovancová et al., 2012).

\subsection{MUTUAL FUNDS}

Mutual funds are instruments used for investment operations. We divide the mutual funds into several categories, depending on purpose, content, and other factors. Unlike investment funds, mutual funds do not have legal personality. They are, therefore, some baskets that associate assets. Mutual funds are managed by investment firms that manage their operations. The basic unit of unit trusts is the unit certificate (ESPA stock Europe-property, 2016).

The professional management of a mutual fund carried out by professional management gives the necessary transparency and a certain guarantee that the fund will meet predetermined investment objectives (Cici et al., 2018; Klučnikov, 2016; Simo et al., 2016; Gavurová et al., 2017; Kolkova , 2018; Korauš et al., 2017; Teresienè, 2018). The Fund's objectives are set out in its Statute, which contains information on the particular fund and profile of the investment company. Expert management is one of the highly valued and expensive services, because every day, fund management analyzes a great deal of new information that seeks to invested money (Haslem, 2009).

Reasons for using mutual funds:

- unlimited units issued,

- unlimited time coverage of the fund - funds are mostly based on indefinite time,

- professional asset management - the investor does not have to follow the development of the market, his/her property is a professional manager,

- free entry and exit from the fund,

- the possibility of diversifying risk - funds mostly manage a wide range of assets,

- pooling effect - thanks to a large amount of fund capital and investors, a small investor can also participate in the yield of securities that he/she could not buy due to a limited size (Radová et al. 2013; Vukovic \& Prosin, 2018; Rahman et al., 2018). 
Associated fund assets reduce some investment costs that would be substantially higher if you invest individually. While an individual investor for each transaction pays his/her securities dealer and mediates to other institutions about one percent of the traded volume, the fund costs are in tenths of a percent (Filip, 2006).

Distribution of mutual funds by content: stock funds, mixed funds, bond funds, money market funds, funds of intangible assets, commodity funds, funds of funds, foreign exchange funds.

Distribution of mutual funds according to the investment strategy: territorial focus funds, sectoral funds, ethical funds, players of large players, emerging economy funds, total return / absolute return funds, dividend funds, protected funds, life cycle funds.

Distribution of mutual funds by target group of investors: mass retail funds, funds for institutional investors, qualified investor funds.

Distribution of mutual funds by management method: actively managed funds, passively managed funds, index funds (Kohout, 2013).

Mutual funds usually carry less risk than if you directly hold individual securities. Funds usually have a large number of securities in their portfolio, which reduces the risk of loss that may be caused, for example, the decline of one security (Filip, 2006; Okoro \& Ekwueme, 2018).

Diversification eliminates the risk of a large loss that may occur if only one security is held and its value is lost. On the other hand, diversification limits the achievement of a high return that can be achieved if only one security is held and its value rises sharply. It should be borne in mind that the investor is by no means completely diversified from the risk of loss in the event of a general decline in financial markets (Steigauf, 2003).

High past equity returns are not a guarantee of future earnings. Funds are often praised for their positive results that have been achieved in the past, but neither are highly educated and successful portfolio managers cannot guarantee future returns.

\subsection{BENCHMARK}

"Benchmark is the benchmark whether the criterion is in evaluating the performance of an investment or depository instrument. For example, we can compare the performance of our own stock portfolio with the development of the official stock exchange index. This index is then a benchmark" (Steigauf, 2003).

"Benchmark is an indicator against which the portfolio's performance is compared. Most often it is one of the market indexes, or a combination of multiple ones. The choice of the index must correspond to the focus of the client's investment strategy, otherwise it loses such a comparison of the verbal ability" (Nenadál et al, 2010).

It is one of the best-known indices, which is mostly taken as a picture of the development of the US stock market. Large investors and a portfolio of managers investing in US stocks use this index as a benchmark to compare the performance of their portfolio. It was created by the wellknown Standard \& Poor rating company in 1957 and is calculated from the stock prices of 500 US companies with the largest market capitalization where the weight of the individual shares in the index is derived from the size of the market capitalization of each company. 
We have included all Franklin Templeton equity funds that have met a 5-year history and benchmark in the form of a stock index.The period from the beginning represents different time frames of the individual funds from foundation of the fund until 31 March 2017. Data was obtained from Franklin Templeton.

\section{METHODOLOGY}

The main purpose of the contribution is to compare the competition of Franklin Templeton Fund managers.

The partial targets of the work are to verify the performance of actively managed equity funds and to verify volatility, therefore, risk in comparison with the benchmark index.

Several recent studies indicate that it does not make sense to try to overcome the benchmark, the market performance. We verify this theory by analyzing actively managed mutual funds with two indicators immediately.

Among the time-tested indicators and suitable ones for our research on validation of an active mutual fund with its benchmark index, we can include the Information ratio and Sharp ratio.

Information ratio - the information ratio pointer tells you how the fund went against the benchmark taking into account the risk, with the higher the number that it did better. If we calculate the negative figure, the fund manager has been inefficient compared to the benchmark.

$I \mathrm{R}=(\mathrm{R}-\mathrm{R} m) /($ Tracking error $)$

$R$ - fund performance over the last 8 years $(\%)$

$\mathrm{R} m$ - market performance, i. index (\%)

Tracking error - annualized standard deviation of the annual performance of the fund and benchmark

Sharp ratio - the original Sharp indicator compares the fund's performance with risk-free returns. We have decided to simplify the calculation and compare the performance of the fund with the performance of the index. In this way, we immediately come to the necessary result and if the result is a positive number, the fund is better than the index if the negative number and the fund manager have been inefficiently managed.

$S R=(R-R f) / s m$

$R$ - fund performance over the last 8 years $(\%)$

$R f$ - index performance $(\%)$

$s m$ - annualized standard deviation of the fund's annual performance $(\%)$

The indicator information ratio measures the ability of the portfolio to generate yield overruns relative to the reference value. The higher the indicator, the better.

The Sharp ratio compares yields with volatility. The modern portfolio theory includes an impor- 
tant investment concept, but it is argued that in exchange for the possibility of a higher risk-free yield, it is possible to undergo a certain degree of risk, therefore, the relationship between yield and risk. The optimal would probably be an investment with the maximum potential of the average yield at minimal risk, but there is a question as to give these two magnitudes into one context. The issue of the relationship between yield and risk was discussed in the past by the distinguished financial theorist and the Nobel Prize laureate, Professor William Forsyth Sharpe (1994). If we have two investments, each with a pre-defined average yield and higher risk (measured, for example, with a standard deviation), the higher-risk investment is the more effective. The Sharp Ratio is determined as the share of the proceeds of the asset valued at risk-free rate and the standard deviation of the yield.

Sharp ratio coefficient is a measure of performance that takes into account the risk profile of the investment. It is the average performance of the asset above the risk-free return of the asset (for example, defined as the proceeds of the treasury bill). If this indicator is higher, the better is the performance of the portfolio due to its risk. It is an indicator of absolute yield without the need for a benchmark (Belás et al. 2018; Kohout, 2013; Belás \& Ključnikov, 2016).

\section{RESEARCH}

In the study, we looked at Franklin Templeton stock fund shares, and whether the active management of managers brings their fruits or, as many studies suggest, is useless.

All data is processed from the Franklin Templeton site. We have analyzed 33 equity funds.

Tab. 1 - Share class. Source: own research

\begin{tabular}{|l|c|c|c|c|c|}
\hline Share class & Beta & $\begin{array}{l}\text { Average of } \\
\text { performance }\end{array}$ & St. Dev. & $\begin{array}{l}\text { Sharpe } \\
\text { ratio }\end{array}$ & $\begin{array}{l}\text { Informa- } \\
\text { tion ratio }\end{array}$ \\
\hline Franklin India Fund & 0,84 & 8,34 & 40,31 & 0,04 & 0,15 \\
\hline MSCI India Index \% & & 6,71 & 46,72 & & \\
\hline Franklin China Fund & 0,93 & 2,05 & 29,62 & $-0,12$ & $-0,6$ \\
\hline MSCI Golden Dragon Index \% & & 5,51 & 31,44 & & \\
\hline Franklin Korea Fund & 0,99 & 0,14 & 35,25 & $-0,16$ & $-0,74$ \\
\hline MSCI Korea Index \% & 0,95 & 12,96 & 38,34 & $-0,02$ & $-0,15$ \\
\hline Franklin Thailand Fund & & 13,78 & 39,93 & & \\
\hline MSCI Thailand Index \% & 0,94 & 1,99 & 34,03 & $-0,07$ & $-0,5$ \\
\hline $\begin{array}{l}\text { Templeton Emerging Markets } \\
\text { Fund }\end{array}$ & & 4,27 & 35,9 & & \\
\hline MSCI Emerging Market Index \% & 0,85 & 7,85 & 41,16 & $-0,02$ & $-0,07$ \\
\hline $\begin{array}{l}\text { Templeton Emerging Markets } \\
\text { Smaller Comp. Fund }\end{array}$ & 1,31 & 7,38 & 45,22 & 0,04 & 0,11 \\
\hline MSCI Emerging Market Index \%
\end{tabular}




\begin{tabular}{|c|c|c|c|c|c|}
\hline $\begin{array}{l}\text { MSCI All Country Asia ex-Japan } \\
\text { Index } \%\end{array}$ & & 5,69 & 33,64 & & \\
\hline Templeton BRIC Fund & 0,99 & 0,53 & 40,55 & $-0,07$ & $-0,86$ \\
\hline MSCI BRIC Index \% & & 3,28 & 40,85 & & \\
\hline Templeton Eastern Europe Fund & 1,1 & 4,06 & 46,47 & $-0,01$ & $-0,03$ \\
\hline $\begin{array}{l}\text { MSCI Emerging Markets Europe } \\
\text { Index } \%\end{array}$ & & 4,4 & 41,34 & & \\
\hline Templeton Latin America Fund & 0,98 & 1,93 & 44,37 & $-0,04$ & $-0,44$ \\
\hline MSCI EM Latin America Index \% & & 3,67 & 45,13 & & \\
\hline $\begin{array}{l}\text { Franklin Global Growth and Value } \\
\text { Fund }\end{array}$ & 1,13 & 4,35 & 25,19 & $-0,05$ & $-0,27$ \\
\hline MSCI All Country World Index \% & & 5,72 & 21,97 & & \\
\hline Franklin Global Growth Fund & 1,26 & 4,65 & 27,93 & $-0,03$ & $-0,08$ \\
\hline $\begin{array}{l}\text { MSCI World (Net Dividends) } \\
\text { Index } \%\end{array}$ & & 5,51 & 20,91 & & \\
\hline $\begin{array}{l}\text { Franklin Global Small-Mid Cap } \\
\text { Growth Fund }\end{array}$ & 1 & 7,6 & 27,28 & $-0,06$ & $-0,17$ \\
\hline $\begin{array}{l}\text { MSCI World Small Cap (Net } \\
\text { Dividends)Index \% }\end{array}$ & & 9,28 & 25.52 & & \\
\hline Franklin Mutual Beacon Fund & 1,02 & 5,88 & 20,61 & $-0,16$ & -1 \\
\hline S\&P 500 Index $\%$ & & 9,12 & 19,97 & & \\
\hline $\begin{array}{l}\text { Franklin Mutual Global Discovery } \\
\text { Fund }\end{array}$ & 0,74 & 4,16 & 16,29 & $-0,12$ & $-0,27$ \\
\hline MSCI World Index \% & & 6,11 & 21,02 & & \\
\hline $\begin{array}{l}\text { Templeton Global Equity Income } \\
\text { Fund }\end{array}$ & 1,01 & 1,11 & 22,63 & $-0,2$ & $-1,14$ \\
\hline MSCI All Country World Index \% & & 5,72 & 21,97 & & \\
\hline Templeton Global (Euro) Fund & 0,95 & 5,56 & 20,54 & $-0,18$ & $-0,53$ \\
\hline MSCI All Country World Index \% & & 9,23 & 20,37 & & \\
\hline Templeton Global Fund & 1,07 & 3,28 & 24,27 & $-0,1$ & $-0,42$ \\
\hline MSCI All Country World Index \% & & 5,72 & 21,97 & & \\
\hline $\begin{array}{l}\text { Templeton Global Smaller Comp. } \\
\text { Fund }\end{array}$ & 1,23 & 5,12 & 33,5 & $-0,13$ & $-0,6$ \\
\hline $\begin{array}{l}\text { MSCI AC World Small Cap In- } \\
\operatorname{dex} \%\end{array}$ & & 9,46 & 27,15 & & \\
\hline Templeton Growth (Euro) Fund & 1 & 6,74 & 19,96 & $-0,15$ & $-0,65$ \\
\hline MSCI World Index \% & & 9,66 & 19,44 & & \\
\hline Franklin U.S. Equity Fund & 0,92 & 5,9 & 18,82 & $-0,17$ & $-0,8$ \\
\hline S\&P 500 Index $\%$ & & 9,12 & 19,97 & & \\
\hline
\end{tabular}




\begin{tabular}{|c|c|c|c|c|c|}
\hline Franklin U.S. Opp. Fund & 1,11 & 8,26 & 24,77 & $-0,08$ & $-0,39$ \\
\hline Russell 3000 Growth Index \% & & 10,31 & 21,93 & & \\
\hline $\begin{array}{l}\text { Franklin U.S. Small-Mid Cap } \\
\text { Growth Fund }\end{array}$ & 0,95 & 8,04 & 25,16 & $-0,11$ & $-0,85$ \\
\hline Russell Mid cap Growth Index \% & & 10,81 & 26,16 & & \\
\hline Templeton Euroland Fund & 0,96 & 4,51 & 22,41 & 0,01 & 0,02 \\
\hline MSCI EMU Index \% & & 4,38 & 22,39 & & \\
\hline Franklin European Growth Fund & 1,1 & 9,21 & 24,75 & 0,14 & 0,46 \\
\hline MSCI Europe Index \% & & 5,72 & 21,57 & & \\
\hline $\begin{array}{l}\text { Franklin European Small-Mid Cap } \\
\text { Grpwth Fund }\end{array}$ & 1,02 & 10,25 & 30,06 & 0,03 & 0,11 \\
\hline $\begin{array}{l}\text { MSCI Europe Small-Mid Cap (Net } \\
\text { Dividends) Index } \%\end{array}$ & & 9,4 & 28,47 & & \\
\hline Franklin Mutual European Fund & 0,87 & 3,73 & 19,17 & $-0,07$ & $-0,25$ \\
\hline $\begin{array}{l}\text { MSCI Europe (Net Dividend) } \\
\text { Index } \%\end{array}$ & & 5,08 & 21,43 & & \\
\hline Templeton European Fund & 0,94 & 4,3 & 21,5 & $-0,07$ & $-0,2$ \\
\hline MSCI Europe Index \% & & 5,72 & 21,57 & & \\
\hline $\begin{array}{l}\text { Franklin Biotechnology Discovery } \\
\text { Fund }\end{array}$ & 0,93 & 15,82 & 24,34 & $-0,05$ & $-0,31$ \\
\hline NASDAQ Biotechnology Index \% & & 17,07 & 25,87 & & \\
\hline Franklin Global Real Estate Fund & 0,81 & 2,93 & 20,84 & $-0,17$ & $-0,48$ \\
\hline $\begin{array}{l}\text { FTSE EPRA/NAREIT Developed } \\
\text { Index } \%\end{array}$ & & 6,57 & 24,8 & & \\
\hline Franklin Natural Resources Fund & 1,25 & 1,08 & 34,34 & $-0,06$ & $-0,2$ \\
\hline $\begin{array}{l}\text { S\&P North American Natural } \\
\text { Resources Sector Index \% }\end{array}$ & & 3,09 & 26,75 & & \\
\hline Franklin Technology Fund & 0,82 & 11,2 & 26,28 & 0 & $-0,02$ \\
\hline $\begin{array}{l}\text { BofA Merrill Lynch } 100 \text { Technol- } \\
\text { ogy Index \% }\end{array}$ & & 11,31 & 31,78 & & \\
\hline Franklin Japan Fund & 1,03 & 1,64 & 27,08 & $-0,14$ & $-0,91$ \\
\hline Tokyo Stock Price Index TOPIX \% & 1,03 & 5,38 & 25,98 & & \\
\hline
\end{tabular}

We tracked all 33 funds together, which would put the performance for the calculation at each year for 8 years. A total of 28 out of 33 Franklin Templeton equity funds failed to overcome the benchmark in the both the information and sharp ratios, forming a negative percentage ratio of $85 \%$. If our research study had been more complex, a number of funds could have been included which were terminated by the company after unsuccessful management, in which cases the particular fund was discontinued. Including this evidence could have addressed a number of issues such as those related to the failure to actively direct managers. 
Since the beta result and the volatility in the case of mutual funds did not show positive results, now only the performance of these funds themselves will be compared to the benchmark and in particular with the costs of management fees, which are calculated annually from the client's total fund value.

Tab. 2 - Exceeded the benchmark. Source: own research

\begin{tabular}{|l|l|l|}
\hline Exceeded the benchmark & 8 & $19 \%$ \\
\hline In 5 years period, analyzed 43 funds & 4 & $13 \%$ \\
\hline In 10 years period, analyzed 30 funds & 4 & $18 \%$ \\
\hline In 15 years period, analyzed 22 funds & 12 & $30 \%$ \\
\hline Analyzed 40 funds from the beginning & 4 & $9 \%$ \\
\hline Exceeded the benchmark with the addition of the fee & 2 & $7 \%$ \\
\hline In 5 years period, analyzed 43 funds & 0 & $0 \%$ \\
\hline In 10 years period, analyzed 30 funds & 3 & $8 \%$ \\
\hline In 15 years period, analyzed 22 funds &
\end{tabular}

In the table it can be seen that each fund as it was created is considered, with the results proving more favorable for administrators. During this period, 40 funds were analyzed in terms of performance, with 12 of them managing to overcome their benchmark according to the index to which they were linked. However, if the management fee of these funds is also taken into consideration, we can see that only 3 funds outperformed the performance benchmark. This is a clear sign of how fees burden fund investment. The worst effect of the charge was shown for the funds in the longest common reference period, during which neither the benchmark for funds with a fee nor for those without them could be overcome.

Table 3 indicates results from the previous table in terms of the number of funds measured, but here we have looked at the average fund lag in terms of performance before and after charges. We can see that in terms of performance Franklin Templeton's equity stocks lagged behind the benchmark from minus $1.08 \%$ to minus $1.99 \%$, but overall results showed a difference from minus $3.11 \%$ to minus $3.99 \%$.

Tab. 3 - Funds averaging below the benchmark. Source: own research

\begin{tabular}{|l|l|}
\hline \multicolumn{2}{|l|}{ Average stagnated behind the benchmark } \\
\hline In 5 years period & -1.95 \\
\hline In 10 years period & -1.99 \\
\hline In 15 years period & -1.62 \\
\hline From the beginning & -1.08 \\
\hline
\end{tabular}




\begin{tabular}{|l|l|}
\hline \multicolumn{2}{|l|}{ Average stagnated behind the benchmark with the addition of the fee } \\
\hline In 5 years period & -3.98 \\
\hline In 10 years period & -3.99 \\
\hline In 15 years period & -3.66 \\
\hline From the beginning & -3.11 \\
\hline
\end{tabular}

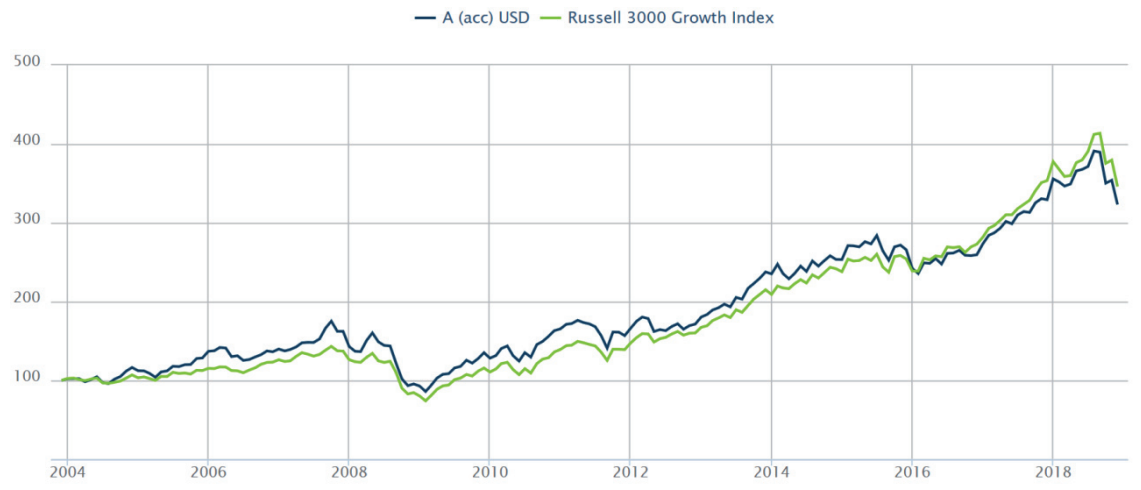

Fig. 1 - Performance of Franklin U.S. Opportunities Fund vs. Russell 3000 Growth Index. Source: Franklin U.S. Opportunities Fund (2018).

In the graph, we can see the performance of the Franklin U.S. Opp. fund compared to its benchmark Russell 3000 Growth Index. This fund lagged by $2.06 \%$ if annual management fees are not counted. The Sharpe ratio of this fund is minus 0.08 , with the information ratio minus 0.39 . We see that this fund, which is one of the most prominent assets of the developed US market, does not perform up to index standards, lagging behind in terms of performance and risk.

It would be interesting to look at the management of specific fund managers, such as shown in the article "Luck Versus Skill in the Cross Section of Mutual Fund Returns." The writers Eugene Fama and Kenneth French found that if better results were in fact achieved, which was not often the case, it was a coincidence and not the result of the exceptional capabilities of the managers involved.

\section{DISCUSSION}

The only argument that the active administrators of cache portfolios can use is that in a crisis the results of administered portfolios is better than those of a passive investor investing in indexes. This, however, is not necessarily true at all. As we and many other authors have shown, the investor cannot predict the market under any conditions, so whether a crisis exists or not is of no influence. In his book Random Walk on Wall Street, Burton Malkiel has shown that choosing instruments using the Beta coefficient does not guarantee companies with lower bets 
that a portfolio will demonstrate lower volatility. Reversing this claim would be appropriate for our future research, i.e. we could compare the index passive portfolio with an active portfolio in times of crisis.

"So, in the future, will we be able to predict when the crises will come, and in what scope? At present, there is no theoretically verified instrument and I do not even know if some will ever be created. Many suspect that the bubble they are going to rip is ruined once. But they hope to use it again, and they will further inflate it. A positive tool that would give us predictions when the crisis breaks out, we do not have. I would compare it to seismology: You know that there must be an earthquake once and for all, but you do not know whether tomorrow or in ten years." I am afraid that predicting the development of the economy for more than ten years is hardly possible" (Brunovský, 2010).

The popularity of passive index investment management is growing at the moment. Of course, we also have to take into account that if the percentage of investors in the past had been too large, the reasonable valuation of assets might have disappeared. Therefore, it is important for the market to have active investors. Nevertheless, it must be said that this type of investment is not suitable for everyone, and for most investors it is more appropriate to passively invest in indexes.

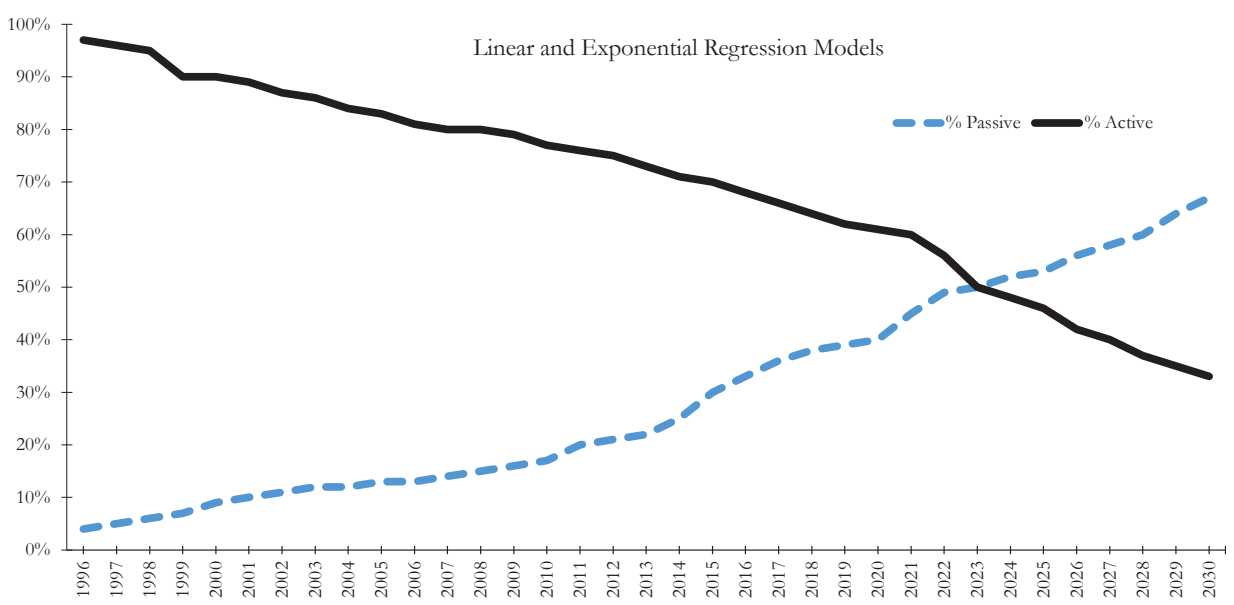

Fig. 2 - Linear and exponential regression models. Source: Moody's. (2017)

In graph 1, we can see a resultant increase from investing passively. More and more passive investors are emerging, and it is estimated that the percentage of these investors will overtake active investors in 2024. Of course, this is an estimate and we have shown that what the market will become can hardly be predicted. Investors have found ways to passively invest, and these soy investors are firmly on the ground, with low fees that do not burden their portfolio unnecessarily and do not eliminate a significant part of their future potential profits. This is a stable way for a sensible investor to realize his/her shortcomings and lack of experience of portfolio manager 
thinking. When investing actively, there are many factors along with unknowns that even active administrators with large budgets could not detect, thus they overcome their benchmark nor the equity index.

"The fact is, that the clients of most traditional mutual funds would be considerably better off if the fund employees just shut their firms down, re-allocated their client's money to low-cost index funds, and found other work to do" (Blodget, 2011).

\section{CONCLUSION}

We can note that in the longest single time period of 15 years out of 22 equity funds, only the results of four funds exceeded the benchmark. On the other hand, if we also include regular fees of the funds measured to reflect more accurately the benefits for the investor, the benchmark in this period was in fact not met.

The information ratio indicator shows how a fund behaves in relation to a benchmark, also taking into account risk. The higher the positive number is, the higher the result than the benchmark was shown for the investors of the fund in question. The higher the negative number is, the more the fund has invested inefficiently against its benchmark.

Overall, 28 out of 33 Franklin Templeton equity pools subjected to this analysis showed a negative informational ratio and negative Sharp ratio. These results support claims that index investment may be better for non-professional and possibly professional investors than to maintain a portfolio directed by fund managers. Investors are particularly burdened with annual management fees that are much higher than in index investment, and coupled with the fact that managers are unable to overcome their benchmark, i.e. the index pool to which they are bound, it is highly questionable whether professional asset management is worth the costs involved.

These claims have already been shown in the latest studies, i.e. it is not always the best choice to put funds into the hands of the portfolio managers because of the costs involved. Recent studies have indicated that managers are unduly competitive, although their results in terms of competitiveness is low. On the other hand, if the investor wants to take on active portfolio management himself/herself, he/she is burden with a high fee and uncertain outcome, thus is unlikely to succeed.In our next research, it would also be interesting to deal with other renowned asset management and active management approaches to the stock portfolio. Complementary research on other indicators like the Jensen alpha, or even more advanced methods would be needed. Concerning index investment, other well-known tools be might be considered for various classes of investors, e.g. a replicable ETF with which a certain type of investor could achieve even better results due to lower costs. Of course, ETFs and mutual funds are of a different nature than other instruments and a comparison between these and other investment modes will be the subject of further research.

\section{Acknowledgement}

The article was developed as part of the Sustainability Assessment of Innovation Implementation for Smart Specialization in Enterprises in SR and on EU Level with Project Number I-18-109-00. 


\section{References}

1. Barras, L., Scaillet, O., \& Wermers, L. (2006). False Discoveries in Mutual Fund Performance: Measuring Luck in Estimated Alphas. 49. Available at: http://web.mit.edu/ econometrics/fdr2version.pdf.

2. Belás, J., Gavurová, B., \& Toth, P. (2018). Impact of selected characteristics of SMEs on the capital structure. Journal of Business Economics and Management, 19 (4), 592-608. https://doi. org/10.3846/jbem.2018.6583.

3. Belás, J., \& Ključnikov, A. (2016). The Most Important Attributes Of Entrepreneurs. Case Study Of The Environment Of Czech SMEs. International Journal of Entrepreneurial Knowledge, 1 (4), 104-111. https://doi.org/10.1515/ijek-2016-0008.

4. Blodget, H. (2011). The Mutual Fund Industry Is A Huge Scam That Costs Investors Billions Of Dollars A Year. Available at: http://www.businessinsider.com/david-swensenmutual-funds-2011-8\#comment-4e483fceecad042b1100002b\#ixzz1V2eCSNyb.

5. Bogle, J. (2007). The Little Book of Common Sense Investing: The Only Way to Guarantee Your Fair Share of Stock Market Returns. New Jersey: John Wiley \& Sons.

6. Brunovský, P. (2010). We do not have time for a night off. Trend, 50-51. Available at: https://www.etrend.sk/ekonomika/chyba-nam-cas-na-bezsenne-noci-2.html.

7. Cici, G., Gehde-Trapp, M., Goericke, MA, \& Kempf, A. (2018). The Investment Value of Fund Managers' Experience outside the Financial Sector. Review of financial studies, 31 (10), 3821-3853. https://doi.org/10.1093/rfs/hhy019.

8. Chovancová, B. et al. (2012). Komoditné trhy a reálne investície. Bratislava: Iura Edition.

9. ESPA stock Europe-property. (2016). Available at: https://cz.products.erstegroup.com/ Retail/cs/Produkty/Fondy/Factsheety/Fund_gene ral/index.phtml?q=\&ISIN=AT000061 3625\&ID_NOTATION.

10. Filip, M. (2006). Personal and family wealth. Praha: C.H.Beck.

11. Franklin euro short-term money market fund. (2016). Available: http://www. franklintempleton.cz/cscz/investor/fondy/fund-detail/13828/Franklin-Euro-Short-TermMoney-MarketFund.

12. Franklin mutual European fund. (2016). Available at: http://www.franklintempleton.cz/cscz/investor/fondy/funddetail/4820/Franklin-Mutual-European-Fund.

13. Franklin U.S. Opportunities Fund. (2018). Franklin Templeton Investment Funds. Available at: https://www.franklintempleton.sk/sk-sk/investor/fondy/performance/4913/ Franklin-U.S.-Opportunities-Fund/V\%C3\%BDkonnos\%C5\%A5

14. Galloppo, G., \& Aliano, M. (2018). Fund Manager Performance in Emerging Market: Factor Specialisation and Financial Crisis Impact. Journal of Emerging Market Finance, 17 (1), 130-158. https://doi.org/10.1177/0972652717748101.

15. Gavurová, B., Belás, J., Kočišová, K. \& Klieštik, T. (2017). Comparison of selected methods for performance evaluation of Czech and Slovak commercial banks. Journal of Business Economics and Management, 18 (5), 852-876. https://doi.org/ 10.3846/16111699.2017. 1371637. 
16. Haslem, J. A. (2009). Mutual funds: portfolio structures, analysis, management, and stewardship. Hoboken, NJ: Wiley.

17. Horecký, J. (2018). Operation and action of a trade union (in terms of the Czech Republic labour law). Central European Journal of Labour Law and Personnel Management, 1 (1), 17-27. https://doi.org/10.33382/cejllpm.2018.01.02.

18. Kljucnikov, A. (2016). Uncover SMEs finance through the impact of the specific factors. evidence from Slovakia. Transformations in Business and Economics, 15(2B), 741-754.

19. Kohout, P. (2013). Investment strategy for the third millennium. Praha: Grada.

20. Kolkova, A. (2018). Indicators of Technical Analysis on the Basis of Moving Averages as Prognostic Methods in the Food Industry. Journal of Competitiveness, 10 (4), 102-119. https:// doi.org/10.7441/joc.2018.04.07.

21. Korauš, A., Dobrovič, J., Rajnoha, R., \& Brezina, I. (2017). The safety risks related to bank cards and cyber attacks. Journal of Security and Sustainability Issues, 6 (4), 563-574. http://doi. org/10.9770/jssi.2017.6.4(3).

22. Korauš, A., Gombár, M., Kelemen, P., \& Backa, S. (2019). Using quantitative methods to identify insecurity due to unusual business operations. Entrepreneurship and Sustainability Issues, 6 (3), 1101-1112. https://doi.org/10.9770/jesi.2019.6.3(3).

23. London Stock Exchange Group. (2016). Available at: http://www.lseg.com/about-londonstock-exchange-group/what-we-do.

24. Malkiel, B. (2007). The Little Book on Common Sense Investing. Available at: https:// www.etf.com/sections/features/7578--malkiel-systemic-risks-lurk-in-developed-world. html? nopaging $=1$.

25. Marszk, A. (2018). Exchange-traded products in Germany: development and substitution of exchange-traded funds, exchange-traded commodities and exchange-traded notes. Equilibrium. Quarterly Journal of Economics and Economic Policy, 13 (4), 643-665. https://doi. org/10.24136/eq.2018.031.

26. Moody's. (2017). Available at: Linear and exponential regression models. https://www. moodys.com/researchandratings/market-segment/funds-asset-management/moneymarket-funds/

27. Mura, L., Daňová, M., Vavrek, R., \& Dúbravská, M. (2017). Economic freedom - classification of its level and impact on the economic security. AD ALTA-journal of Interdisciplinary Research, 7 (2), 154-157.

28. Mura, L., \& Vlacseková, D. (2018). Motivation of public employees: case study of Slovak teaching and professional staff. Administrative in Management Public, (31), 67-80, https://doi. org/10.24818/amp/2018.31-05.

29. Nenadál, J. et al. (2010). Benchmarking - Myths and Reality. Management Press.

30. Okanazu, O. O. (2018). Financial management decision practices for ensuring business solvency by small and medium scale enterprises. Acta Oeconomica Universitatis Selye, 7 (2), 109-121. 
31. Okoro, E. G., \& Ekwueme, C. M. (2018). Determinants of bank performance in Nigeria: the dynamics of internality and externality measures. Acta Oeconomica Universitatis Selye, 7 (1), $108-120$.

32. Olivares-Caminal, R., \& Bodellini, M. (2018). The UK regulation on alternative investment fund managers: a difficult compromise between two different legislative approaches. Journal of banking regulation, 19 (1), 73-85, SI. https://doi.org/ 10.1057/s41261-017-0052-1.

33. Poliačiková, E. (2015). Key accout management as an inovation form of entry to customers in Slovakia. Acta Oeconomica Universitatis Selye, 4 (1), 135 - 145.

34. Radová, J., Dvořák, P., \& Málek, J. (2013). Financial mathematics for everyone. Praha: Grada.

35. Rahman, A., Rozsa, Z., \& Cepel, M. (2018). Trade Credit and Bank Finance - Evidence from the Visegrad Group. Journal of Competitiveness, 10 (3), 132-148. https://doi.org/10.7441/ joc.2018.03.09.

36. Roubini, N. (2018). This Will Trigger the Next Crisis. Available at: https://www. investopedia.com/news/roubini-will-trigger-next-crisis/.

37. Simo, D., Mura, L., \& Buleca, J. (2016). Assessment of milk production competitiveness of the Slovak Republic within the EU-27 countries. Agricultural Economics-Zemedelska Ekonomika, 62 (10), 482-492. https://doi.org/10.17221/270/2015-AGRICECON.

38. Sosnowski, T. (2018). Earnings management in the private equity divestment process on Warsaw Stock Exchange. Equilibrium. Quarterly Journal of Economics and Economic Policy, 13 (4), 689-705. https://doi.org/10.24136/eq.2018.033.

39. Steigauf, S. (2003). Funds: how to make money with funds. Praha: Grada, 1st edition.

40. Teresiene, D. (2018). Performance measurement issues in central banks. Entrepreneurship and Sustainability Issues, 6 (1), 176-189. https://doi.org/10.9770/jesi.2018.6.1(12).

41. Veselovská, S., Korauš, A., \& Polák, J. (2018). Money Laundering and Legalization of Proceeds of Criminal Activity. Second International Scientific Conference on Economics and Management - EMAN 2018. https://doi.org/10.31410/EMAN.2018.

42. Vukovic, D. B., \& Prosin, V. (2018). The prospective low risk hedge fund capital allocation line model: evidence from the debt market. Oeconomia Copernicana, 9 (3), 419-439. https:// doi.org/10.24136/oc.2018.021.

43. Vychytilova, J. (2018). Stock market development beyond the GFC: the Case of V4 Countries. Journal of Competitiveness, 10 (2), 149-163. https://doi.org/10.7441/joc.2018.02.10.

44. Žulová, J., Švec, M., \& Madleňák, A. (2018). Personality aspects of the employee and their exploration from the GDPR perspective. Central European Journal of Labour Law and Personnel Management, 1 (1), 68-77. https://doi.org/10.33382/cejllpm.2018.01.05. 


\section{Contact information}

doc. RNDr. Zuqana Hajduova, PhD.

University of Economics in Bratislava

Faculty of Business Management

Slovak Republic

zuzana.hajduova@euba.sk

Ing. Miroslav Klimek

University of Economics in Bratislava

Faculty of Business Management

Slovak Republic

miroslav.klimek@student.euke.sk

doc. Ing. Naqibullah Daneshjo, PhD.

University of Economics in Bratislava

Faculty of Business Administration based in Košice

Department of Business

Slovak Republic

naqibullah.daneshjo@euke.sk.

prof. Dr. Olha Prokopenko, PhD.

International Humanities University in Odessa

Professor at the Economics and International Economic Relations Department

Director of the Center for European Education and Research

Ukraine

prokopenko.olha.w@gmail.com 